\title{
Use of Carbon Sources for Lipid Biosynthesis in Mycobacterium leprae: a Comparison with Other Pathogenic Mycobacteria
}

\author{
By P. R. WHEELER* AND C. RATLEDGE \\ Department of Biochemistry, University of Hull, Hull HU6 $7 R X, U K$
}

(Received 30 March 1988)

\begin{abstract}
Carbon from glycerol and palmitate, but not significantly from five other carbon sources tested, was incorporated into lipids by suspensions of non-growing Mycobacterium leprae organisms. However, of the five other substrates three - citrate, glucose and pyruvate - were taken up. Nongrowing Mycobacterium microti and Mycobacterium avium incorporated carbon into lipids from most simple carbon sources tested unless they were obtained from growth media including palmitate or from experimentally infected animals, when incorporation of carbon into lipids from carbon sources except palmitate occurred up to 20 times more slowly. Thus, utilization of simple carbon appeared to be repressible while utilization of the one fatty acid tested, palmitate, appeared constitutive. In $M$. leprae, carbon from glycerol was incorporated into the glycerol moiety of acylglycerols but not into the fatty acid moieties or into free fatty acids. $M$. microti and $M$. avium incorporated carbon from simple carbon sources into fatty acids, even (though very slowiy) when these organisms were obtained from host tissue. Isocitrate lyase, malate synthase and acetate kinase were detected in $M$. leprae. However acetyl-CoA synthetase was not detectable and phosphoacetylase was deficient; thus, $M$. leprae may be incapable of making acetyl-CoA from acetate. Phosphotransacetylase was readily detected in both host-grown $M$. avium and $M$. microti.
\end{abstract}

\section{INTRODUCTION}

The ability to acquire carbon sources and use them to synthesize lipids is crucial for Mycobacterium leprae as, like most other mycobacteria, about $40 \%$ of its dry weight is lipid material (Ratledge, 1982). Moreover, like a number of pathogenic mycobacteria, $M$. leprae excretes large quantitites of lipid into its environment. Tissue infected with the leprosy bacillus, $M$. leprae, contains up to $166 \mu \mathrm{g}$ of a characteristic phenolic glycolipid for each $\mathrm{mg}$ dry wt of $M$. leprae (Cho et al., 1986).

Although the identity of many lipids of $M$. leprae is known (Brennan, 1983; Draper, 1984), the substrates and metabolic pathways for lipid biosynthesis have not yet been shown in isolated leprosy bacilli. However, it is known that $M$. leprae takes up a number of carbon sources and can oxidize them to $\mathrm{CO}_{2}$ (Wheeler, 1983, 1984a). Therefore, in this work the incorporation of various ${ }^{14} \mathrm{C}$-labelled substrates into lipid in $M$. leprae was ascertained. Previously, enzymes of glycolysis, the hexose monophosphate pathway (Wheeler, 1983) and tricarboxylic acid cycle (Wheeler, 1984a) were demonstrated in $M$. leprae. In this work, enzymes that might be involved in channelling carbon sources into lipid synthesis or involved in the metabolism of carbon derived from lipids were sought - i.e. enzymes for converting acetate and pyruvate to acetyl$\mathrm{CoA}$ and the enzymes of the glyoxylate cycle.

Lipid biosynthesis and the related metabolic activities mentioned above are known to be regulated in mycobacteria (Bloch, 1977; Ratledge, 1982). Such activities may well be repressed or inhibited when mycobacteria are growing inside host tissue where lipids might be available as

Abbreviations: HPTLC, high performance thin layer chromatography; DTNB, dithio-bis(2-nitrobenzoic acid). 
a carbon source. Therefore, all activities sought in $M$. leprae have been compared to those in $M$. microti and $M$. avium grown in vivo and in vitro in an attempt to determine whether the findings with $M$. leprae indicated possible metabolic incompetences in areas of lipid biosynthesis or whether $M$. leprae uses carbon sources for lipid biosynthesis in a way similar to other pathogenic mycobacteria when they are growing inside a host.

Additionally, $M$. avium and $M$. microti were grown in media with a single modification - such as the addition of a fatty acid - in an attempt to find out the effects of some exogenous carbon sources in lipid metabolism. Any deficiencies in metabolism in $M$. leprae that might be deduced from these studies might help in understanding why it cannot, as yet, be grown in axenic culture.

\section{METHODS}

Mycobacteria from experimentally infected animals. $M$. leprae was harvested from armadillo liver and spleen, M. avium CR1/69 (from AFRC Institute for Research in Animal Diseases, Compton, nr Newbury, Berkshire, UK) from spleen and liver of C57 Black mice, and M. microti OV 254 (from National Institute for Medical Research, London, UK) from lungs of CBA mice. Experimental infections and harvesting methods (World Health Organization, 1980) have both been described previously (Wheeler, 1987). Briefly, the bacteria were separated from tissue by a method including density gradient centrifugation using Percoll (Pharmacia). For suspensions which were sonicated to provide cell-free extracts for enzyme work, further purification was achieved in an aqueous two-phase system. Some suspensions were treated for $30 \mathrm{~min}$ with $0.5 \mathrm{M}-\mathrm{NaOH}$ at $25^{\circ} \mathrm{C}$ (Wheeler et al., 1982) to abolish host-derived activities adsorbed to the surface of the mycobacteria.

Mycobacteria grown in cell-free media. M. avium and M. microti were grown in Modified Dubos medium alone, or with the following additions: (i) $1 \%$ (w/v) glycerol; (ii) $100 \mu \mathrm{g}$ sodium palmitate $\mathrm{ml}^{-1}$. These are referred to as Dubos medium, and Dubos medium with added glycerol or palmitate, in the Results and Discussion. Modified Dubos medium (see Chadwick, 1982) includes citrate, asparagine and Casamino acids as carbon sources as well as Tween 80. For some experiments, mycobacteria were grown in Modified Dubos medium with Tween 80 omitted. M. microti was also grown in Youmans and Karlson medium (see Chadwick, 1982) - which includes asparagine, glycerol and citrate only as carbon sources - plus $0.4 \%$ bovine serum albumin. Little or no growth was obtained when palmitate was added to Youmans and Karlson medium so it was not used in the principal experiments reported in this paper. All mycobacteria used in experiments were grown for $14 \mathrm{~d}$ at $37^{\circ} \mathrm{C}$ in $100 \mathrm{ml}$ medium in shaking (200 r.p.m.) $250 \mathrm{ml}$ flasks stoppered with polyurethane bungs. The inoculum was a suspension $(1 \mathrm{ml})$ grown previously in the same medium. After growth, bacteria were washed aseptically three times in buffered Tween $80(0.1 \%$, w/v, Tween 80 in $1.5 \mathrm{mM}-\mathrm{MES}, \mathrm{pH} 7.0)$ or, when grown in Modified Dubos medium without Tween 80, washed twice in $10 \mathrm{mM}-\mathrm{MES} / \mathrm{KOH}, \mathrm{pH} 7.0$.

Preparation of cell-free extracts. These were prepared by ultrasonic disruption of bacteria as described previously (Wheeler \& Gregory, 1980). Portions of some extracts were dialysed using ultrafiltration cones with a cut-off of $M_{\mathrm{r}}$ 25000 as described previously (Wheeler, 1984a).

Extracts of armadillo tissue. An extract was prepared at pH 8.7 (the $\mathrm{pH}$ of the initial homogenate of infected tissue from which mycobacteria are harvested) as described previously (Wheeler \& Gregory, 1980).

Radioisotopically labelled substrates. [U-1 $\left.{ }^{14} \mathrm{C}\right] \mathrm{Palmitic}$ acid $\left(402 \mathrm{Ci} \mathrm{mol}^{-1} ; 14.9 \mathrm{GBq} \mathrm{mmol}{ }^{-1}\right),\left[2-{ }^{14} \mathrm{C}\right]$ acetic acid, sodium salt $\left(56 \mathrm{Ci} \mathrm{mol}^{-1} ; 2.07 \mathrm{GBq} \mathrm{mmol}{ }^{-1}\right),\left[\mathrm{U}^{-14} \mathrm{C}_{\text {glycerol }}\left(170 \mathrm{Ci} \mathrm{mol}^{-1} ; 6.3 \mathrm{GBq} \mathrm{mmol}{ }^{-1}\right),\left[1^{-14} \mathrm{C}\right]\right.$ pyruvic acid, sodium salt $\left(26 \mathrm{Ci} \mathrm{mol}^{-1} ; 0.96 \mathrm{GBq} \mathrm{mmol}^{-1}\right),\left[2-^{-14} \mathrm{C}\right]$ malonic acid, sodium salt $\left(20 \mathrm{Ci} \mathrm{mol}^{-1} ; 0.74 \mathrm{GBq}\right.$ $\left.\mathrm{mmol}^{-1}\right)$, [U-14 $\mathrm{C}_{\text {glucose }}\left(270 \mathrm{Ci} \mathrm{mol}^{-1} ; 10.0 \mathrm{GBq} \mathrm{mmol}^{-1}\right.$ and $\left[1,5{ }^{-14} \mathrm{C}\right]$ citric acid $\left(170 \mathrm{Ci} \mathrm{mol}^{-1} ; 6.3 \mathrm{GBq}\right.$ $\left.\mathrm{mmol}^{-1}\right)$ were obtained from Amersham; $\left[2-{ }^{-14} \mathrm{C}\right]$ pyruvic acid, sodium salt $\left(12.5 \mathrm{Ci} \mathrm{mol}^{-1} ; 0.46 \mathrm{GBq} \mathrm{mmol}^{-1}\right)$ was obtained from New England Nuclear.

Incubations of mycobacteria with radioisotopically labelled substrates. Bacteria $\left(0.25\right.$ to $2.0 \times 10^{10} ; 10^{10} \mathrm{M}$. leprae weigh approximately $1 \mathrm{mg} \mathrm{dry} \mathrm{wt}$ ) as washed suspensions in buffered Tween 80 , were incubated with ${ }^{14} \mathrm{C}$-labelled substrates as follows: acetate, glucose, citric acid each at $0.5 \mu \mathrm{Ci}(18.5 \mathrm{kBq}), 0.1 \mathrm{mM}$ : glycerol (except where otherwise stated), pyruvic acid each at $0.25 \mu \mathrm{Ci}(9.25 \mathrm{kBq}), 0.1 \mathrm{~mm}$; malonic acid at $0.4 \mu \mathrm{Ci}(14.8 \mathrm{kBq}), 0.1 \mathrm{~mm}$ and palmitic acid at $0.8 \mu \mathrm{Ci}(29.6 \mathrm{kBq})(2 \mathrm{nmol})$. Since palmitic acid was supplied as a solution in toluene, the $2 \mathrm{nmol}$ portions were transferred into each incubation vial and the toluene was allowed to dry under aseptic conditions. All incubation mixtures were made up to a final volume of $200 \mu \mathrm{l}$ which included one labelled substrate, bacteria, and the following adjusted to $\mathrm{pH} 7$ with $\mathrm{KOH}$ : HEPES (50 mM), $\mathrm{MgSO}_{4}(5 \mathrm{~mm})$, $\mathrm{Na}_{2} \mathrm{HPO}_{4} / \mathrm{KH}_{2} \mathrm{PO}_{4}(1 \mathrm{mM})$ and penicillin $\mathrm{G}\left(50 \mathrm{U} \mathrm{ml}^{-1}\right)$. Incubations were at $34^{\circ} \mathrm{C}$; for $M$. microti and $M$. avium they were done for up to $2 \mathrm{~h}$; for $M$. leprae, for $20 \mathrm{~h}$. After $20 \mathrm{~h}$ incubations, a $5 \mu l$ sample was taken aseptically, and plated on to nutrient agar to check for any contamination - contaminated incubations were discarded. ${ }^{14} \mathrm{CO}_{2}$ evolved during incubation was trapped in $400 \mu \mathrm{l} 1 \mathrm{M}-\mathrm{NaOH}$. Assimilation of radioactivity into lipids was determined by collecting and washing the bacteria on filters as for determination of assimilation, then extracting 
the bacteria (still on the filters) for $1 \mathrm{~h}$ with $4 \mathrm{ml}$ hot chloroform/methanol/1 $\mathrm{M}-\mathrm{HCl}(16: 6: 1$, by vol.), removing and discarding the filters, washing the organic solvent phase once with $5 \mathrm{ml}$ distilled water, removing any solid material in the solvent (bacteria, glass fibres from the filter) by filtration through Millipore Millex-HV $4 \mathrm{~mm}$ filters and evaporating the solvent in scintillation vials.

Radioactivity was determined - as ${ }^{14} \mathrm{CO}_{2}$ in $\mathrm{NaOH}$, on filters, or in extracted lipids - by adding $10 \mathrm{ml}$ Bray's scintillation fluid $(4 \mathrm{~g}$ 2,5-diphenyloxazole, $60 \mathrm{~g}$ naphthalene, $100 \mathrm{ml}$ methanol, $20 \mathrm{ml}$ ethanediol made up to 11 with dioxan), mixing thoroughly and scintillation counting at least $3 \mathrm{~h}$ after addition of scintillation fluid to the radioactive material. Controls contained: (i) heat-killed bacteria $\left(100^{\circ} \mathrm{C}, 15 \mathrm{~min}\right)$; (ii) formaldehyde-killed bacteria $\left(18 \mathrm{~h}\right.$ at $20^{\circ} \mathrm{C}$ in $10 \%, \mathrm{v} / \mathrm{v}$, formalin, followed by three washes, by centrifugation and resuspension in buffered Tween 80 , of the killed bacteria); or (iii) live bacteria added to incubation media and collected immediately. In controls (i) and (ii) incubations were for the same period as parallel incubations with live bacteria. Controls (i), (ii) and (iii) had similar background radioactivity (except where shown in the results) and d.p.m. in controls is always subtracted from d.p.m. in incubations in the results.

Fractionation of neutral lipids. Labelled lipid material for fractionation was obtained by collecting and washing bacteria on filters as for determination of assimilation but then boiling in ethanol for $10 \mathrm{~min}$, cooling, and extracting with $4 \mathrm{ml}$ chloroform/methanol $/ 1 \mathrm{M}-\mathrm{HCl}$ at $20^{\circ} \mathrm{C}$ for $18 \mathrm{~h}$. The organic solvent phase was washed with distilled water, filtered through Millex-HV $4 \mathrm{~mm}$ filters into glass tubes and evaporated. The material (at least $80 \%$ of the total) was applied to HPTLC plates (Merck; HPTLC silica gel 60 with concentrating zone) by adding $15 \mu \mathrm{l}$ chloroform to each tube to dissolve it, applying to plates, and repeating the procedure twice. Unlabelled palmitate $\left(R_{F} \sim 0.55\right)$, monopalmitoylglycerol (MPG; $\left.R_{F} \sim 0.05\right)$, dipalmitoylglycerol (DPG; $\left.R_{F} \sim 0.30\right)$ and tripalmitoylglycerol (TPG; $\left.R_{F} \sim 0.75\right)(20 \mu \mathrm{g}$ each) were applied as carriers (fatty acyl chain length and saturation did not affect mobilities). The plates were developed once in light petroleum (b.p. $60-80^{\circ} \mathrm{C}$ )/diethyl ether/glacial acetic acid ( $90: 10: 1$, by vol.), and the position of lipids ( $R_{F}$ values given above) was detected non-destructively by spraying with $0.2 \% 2,7$-dichlorfluorescin in ethanol/water $(96: 4, \mathrm{v} / \mathrm{v})$. Spots corresponding to the above mentioned lipids, and areas of plate between spots, were scraped into scintillation vials, Bray's solution (see above) was added, and their radioactivity was determined by scintillation counting. The HPTLC method used in this work was based on a TLC method for separating neutral lipids of $M$. smegmatis (Dhariwal et al., 1978).

Enzyme assays. All were done at $25^{\circ} \mathrm{C}$; the reaction volume was $500 \mu \mathrm{l}$ unless otherwise stated. Assay conditions were optimized in previous studies (see below and Reddy \& Venkitasubramanian, 1975) and similar pH, as well as concentrations of substrates and metal ions were used in the present work. However, some assays were modified to improve their sensitivity. Pyruvate dehydrogenase [EC 1.2.4.1; pyruvate oxidoreductase (decarboxylating and acceptor acetylating)] and isocitrate dehydrogenase [EC 1.1.1.42; threo- $\mathrm{D}_{\mathbf{s}}$-isocitrate : NADP oxidoreductase (decarboxylating)] were assayed as described previously (Wheeler, 1984a).

Acetate kinase (EC 2.7.2.1; ATP : acetate phosphotransferase) was assayed by incubating extracts with $100 \mathrm{~mm}$-sodium acetate (adjusted to $\mathrm{pH} 7 \cdot 6$ ), $1 \mathrm{mM}-\mathrm{MgCl}_{2}, 1 \mathrm{mM}-\mathrm{MnCl}_{2}, 5 \mathrm{~mm}$-ATP, $1 \mathrm{~mm}$-phosphoenolpyruvate and $100 \mathrm{~mm}$-triethanolamine/ $\mathrm{HCl}(\mathrm{pH} 7.6)$ plus the coupling mixture $0.2 \mathrm{mM}-\mathrm{NADH}$ and a lactate dehydrogenase/ pyruvate dehydrogenase from rabbit muscle (Sigma; $200 \mathrm{U} \mathrm{ml}^{-1}$ and $32 \mathrm{U} \mathrm{ml}^{-1}$ respectively). The decrease in $A_{340}$ in incubations with and without acetate was measured, the difference being proportional to acetate kinase activity. When background oxidation of NADH (i.e. without acetate) was very high, it was inhibited by adding 0.4 mM quinacrine dihydrochloride (Sigma; adjusted to $\mathrm{pH} 7.6$ with Tris base). Quinacrine did not inhibit acetate kinase activity. Optimum assay conditions were established previously with the enzyme from $M$. phlei and M. bovis BCG (Andrejew et al., 1975).

Phosphotransacetylase (EC 2.3.1.8; acetyl-CoA: orthophosphate acetyltransferase) was assayed by incubating extracts with $1 \mathrm{~mm}$-acetyl-CoA, $19 \mathrm{mM}-\left(\mathrm{NH}_{4}\right)_{2} \mathrm{SO}_{4}, 0 \cdot 1 \mathrm{mM}-5,5^{\prime}$-dithio-bis(2-nitrobenzoic acid) (DTNB; added as a $10 \mathrm{~mm}$-stock solution in dimethylsulphoxide), $20 \mathrm{mM}$-sodium phosphate, $\mathrm{pH} 7 \cdot 5$, and $86 \mathrm{mM}-\mathrm{Tris} / \mathrm{HCl}$, $\mathrm{pH}$ 7.5. Increase in $A_{412}$ was followed in incubations with or without phosphate, the difference being proportional to phosphotransacetylase activity. An alternative assay, using acetyl phosphate (at $7 \mathrm{mM}$ ) and acetyl-CoA, and following acetyl-CoA formation (increase in $A_{233}$ ), gave specific activities about three times higher in extracts of mycobacteria but was relatively insensitive because of high background $A_{233}$ values and high levels of noise in spectrophotometric readings at this short UV wavelength. Optimum assay conditions were established previously with enzyme from $M$. phlei and $M$. bovis BCG (Andrejew et al., 1976).

$A$ radiochemical assay for formation of acetyl-CoA and acetyl phosphate from acetate was also used. Extracts (44-74 $\mu \mathrm{g}$ protein) were incubated at $25^{\circ} \mathrm{C}$ with $7 \mathrm{mM}$-sodium $\left[2-^{14} \mathrm{C}\right]$ acetate $\left(40 \mu \mathrm{Ci} \mathrm{m} l^{-1} ; 1.48 \mathrm{MBq} \mathrm{ml}^{-1}\right), 30$ $\mathrm{mM}$-Tris/HCl (pH 7.6), $2.5 \mathrm{mM}-\mathrm{MgCl}_{2}, 5 \mathrm{mM}-\mathrm{ATP}, 2 \mathrm{mM}-\mathrm{CoA}-\mathrm{SH}$ (lithium salt) and $2 \mathrm{~mm}$-dithiothreitol in a total volume of $25 \mu \mathrm{l}$. Samples $(5 \mu \mathrm{l})$ were taken immediately, and after 10,25 and $100 \mathrm{~min}$, mixed with $1 \mu \mathrm{l}$ of a mixture of unlabelled acetyl-CoA and acetyl phosphate (both at $50 \mathrm{mg} \mathrm{m}^{-1}$ ), and applied to PEI-cellulose TLC plates (Merck; PEI-cellulose F pre-coated on plastic sheets). The plates were developed in $\mathbf{0} \cdot \mathbf{2} \mathrm{M}$ - $\mathrm{LiCl}$ (solvent front: $180 \mathrm{~mm})$, allowed to dry in air, and sprayed with $0.04 \%$ bromocresol green in ethanol $/$ water $(96: 4, \mathrm{v} / \mathrm{v})$ to identify spots. Areas were cut out as follows: for acetyl-CoA, from origin to $15 \mathrm{~mm}$; for acetyl phosphate, from 45 to 
$75 \mathrm{~mm}$; for acetate, from 120 to $150 \mathrm{~mm}$. Radioactivity in the areas of the TLC plate was determined by scintillation counting in Bray's fluid.

Isocitrate lyase (EC 4.1.3.1; threo- $\mathrm{D}_{\mathbf{s}}$-isocitrate glyoxylate lyase) was assayed in extracts by a modification of the method of Dixon \& Kornberg (1959) using $1.6 \mathrm{mM}$-threo- $\mathrm{L}_{\mathrm{s}}$-isocitrate (Sigma; potassium salt), $5 \mathrm{mM}-\mathrm{MgCl}_{2}, 2$ mM-cysteine. $\mathrm{HCl}, 3.3 \mathrm{mM}$-phenylhydrazine. $\mathrm{HCl}$ and $67 \mathrm{mM}-\mathrm{HEPES} / \mathrm{KOH}, \mathrm{pH} 6.85$ (final pH of mixture 6.4). Increase in $A_{324}$ was followed in incubations with or without isocitrate, the difference being proportional to isocitrate lyase activity. An alternative assay, coupled to glyoxylate reductase, gave specific activity values about three times higher in extracts of mycobacteria but was not very reproducible.

Malate synthase [EC 4.1.3.2; L-malate glyoxylate-lyase (CoA acetylating)] was assayed by incubating extracts with $0.5 \mathrm{mM}$-acetyl-CoA, $0.15 \mathrm{mM}$-glyoxylic acid, $10 \mathrm{mM}-\mathrm{MgCl}_{2}$ and $50 \mathrm{mM}$-Tris $/ \mathrm{HCl}, \mathrm{pH} 7.5$ (reaction volume $250 \mu \mathrm{l}$; controls were done by omitting glyoxylate). After $5 \mathrm{~min}, 250 \mu \mathrm{l} 0.2 \mathrm{mM}-\mathrm{DTNB}$ in $10 \%(\mathrm{v} / \mathrm{v})$ ethanol (from a stock solution of $2 \mathrm{mM}$-DTNB in ethanol) was added to each reaction mixture : enzyme activity was proportional to ( $A_{412}$ in mixtures including glyoxylate) minus $\left(A_{412}\right.$ in corresponding controls). An alternative, continuous assay in which malate formation was coupled to dye reduction by adding malate dehydrogenase, diaphorase, NAD, and p-iodonitrotetrazolium violet formation allowed formation of malate, linear with time, to be followed for $20 \mathrm{~min}$. However, the continuous assay gave specific values about four times lower in extracts of mycobacteria.

Statistical method. Student's $t$-test was used throughout to test significance.

\section{RESULTS}

\section{Incorporation of carbon from exogenous substrates into lipids of $M$. leprae}

$M$. leprae isolated from armadillo tissue readily incorporated carbon (traced using ${ }^{14} \mathrm{C}$ ) only from palmitate and glycerol (amongst carbon sources used in this study) into lipid material (Table 1). Carbon from glucose was detected in lipids at a trace level, 125 to 190 d.p.m. in $10^{10}$ cells of $M$. leprae (see Table 1) in all incubations using $M$. leprae from three separate isolates. In contrast, the trace incorporation of carbon into lipids from pyruvate (Table 1) was not detected in $M$. leprae from all isolates. Exogenous palmitate and glycerol were assimilated by $M$. leprae more rapidly than other carbon sources, but failure to assimilate carbon sources could not explain entirely the limited number of carbon sources used in lipid synthesis. While malonate and acetate were not assimilated by $M$. leprae in the incubation conditions used, glucose and citrate were assimilated, yet little or none of their carbon appeared in lipids. If incubations were done at $\mathrm{pH} 5$ (substituting MES for HEPES in the incubation buffer), acetate was assimilated ( $1.1 \%$ of that supplied exogenously), but still none of the carbon appeared in the lipids. No radioactivity from any source was incorporated into isolated lipid material if incubations were done with just an extract of armadillo liver (1 mg protein) in place of mycobacteria.

\section{Table 1. Incorporation of carbon from substrates into lipids in $M$. leprae}

Incubations were at $\mathrm{pH} 7$ and $34^{\circ} \mathrm{C}$ for $20 \mathrm{~h}$ and included $8 \times 10^{9}$ to $2 \times 10^{10}$ organisms, and $20 \mathrm{nmol}$ ${ }^{14} \mathrm{C}$-labelled carbon source (except palmitate: $2 \mathrm{nmol}$ ) in $200 \mu \mathrm{l}$. Each value represents four to eight incubations from three to five isolates, except in the case of incubations with citrate and malonate, when values represent two or three incubations from two isolates. Values are expressed as the percentage of radioactivity supplied that was (i) assimilated into intact bacteria or (ii) incorporated into lipids (per $10^{10}$ organisms in $20 \mathrm{~h} \pm \mathrm{SEM}$ ). In no incubation was $>16 \%$ of the substrate supplied utilized, including substrate converted to ${ }^{14} \mathrm{CO}_{2}$.

14-C-labelled substrate in
incubation medium

[U-14 C]Palmitate

$\left[2-{ }^{14} \mathrm{C}\right]$ Acetate

$[2-14 \mathrm{C}]$ Pyruvate

$\left[2-{ }^{14} \mathrm{C}\right]$ Malonate

[U-14 C]Glycerol

[U-14 C]Glucose

$\left[1,5^{14} \mathrm{C}\right]$ Citrate
Radioactivity in $M$. leprae

$\begin{array}{rc}\text { Assimilated } & \text { Incorporated into lipids } \\ 2.03 \pm 0.58 & 1.65 \pm 0.52 \\ 0 \pm 0.03 & 0 \pm 0.03 \\ 0.25 \pm 0.07 & 0.07 \pm 0.03^{*} \\ 0 \pm 0.01 & 0 \pm 0.01 \\ 1.85 \pm 0.24 & 0.67 \pm 0.17 \\ 0.50 \pm 0.06 & 0.02 \pm 0.002 \\ 0.11 \pm 0.04 & 0 \pm 0.002\end{array}$

* Doubtfully significantly $(0.05<P<0.10)$ above zero. Except for zeros themselves, all other values are significantly $(P<0.05)$ above zero. 
Table 2. Incorporation of carbon from substrates into lipids in $M$. microti

Incubations were at $34^{\circ} \mathrm{C}$, for $1 \mathrm{~h}$, and included $2.5 \times 10^{9}$ to $1.2 \times 10^{10}$ organisms, and $20 \mathrm{nmol}{ }^{14} \mathrm{C}$ labelled carbon source (except palmitate: $2 \mathrm{nmol}$ ) in $200 \mu \mathrm{l}$. Each value represents three to nine incubations from at least three cultures or isolates, except when bacteria were grown in Dubos + glycerol when values represent two incubations from a single, representative culture. Value are expressed as the percentage of radioactivity supplied that was (i) assimilated into intact bacteria or (ii) incorporated into lipids (per $10^{10}$ organisms per hour \pm SEM). In no incubation was $>25 \%$ of the substrate supplied utilized, including substrate converted to ${ }^{14} \mathrm{CO}_{2}$.

\begin{tabular}{|c|c|c|c|c|c|}
\hline \multirow[b]{2}{*}{$\begin{array}{c}{ }^{14} \mathrm{C} \text {-labelled } \\
\text { substrate in } \\
\text { incubation medium }\end{array}$} & \multirow[b]{2}{*}{$\begin{array}{l}\text { Radioactivity } \\
\text { in } M . \text { microti }\end{array}$} & \multicolumn{4}{|c|}{ Growth medium } \\
\hline & & Dubos & $\begin{array}{l}\text { Dubos }+1 \% \\
\text { glycerol }\end{array}$ & $\begin{array}{c}\text { Dubos }+100 \mu \mathrm{g} \\
\text { sodium palmitate } \mathrm{ml}^{-1}\end{array}$ & CBA mice \\
\hline$\left[\mathrm{U}-{ }^{14} \mathrm{C}\right]$ Palmitate & $\begin{array}{l}\text { Assimilated } \\
\text { In lipids }\end{array}$ & $\begin{array}{l}7 \cdot 4 \pm 1 \cdot 6 \\
6 \cdot 7 \pm 1 \cdot 3\end{array}$ & $\begin{array}{l}13 \cdot 3 \\
11 \cdot 5\end{array}$ & $\begin{array}{l}6.6 \pm 0.46 \\
6.0 \pm 0.98\end{array}$ & $\begin{array}{r}12 \cdot 8 \pm 3 \cdot 3 \\
9.6 \pm 3.2\end{array}$ \\
\hline$\left[2-{ }^{14} \mathrm{C}\right]$ Acetate & $\begin{array}{l}\text { Assimilated } \\
\text { In lipids }\end{array}$ & $\begin{array}{r}13 \cdot 6 \pm 1 \cdot 5 \\
8 \cdot 2 \pm 1 \cdot 4\end{array}$ & $\begin{array}{l}6 \cdot 2 \\
3.8\end{array}$ & $\begin{array}{r}1.2 \pm 0.39 \\
0.27 \pm 0.09\end{array}$ & $\begin{array}{c}1.2 \pm 0.36 \\
0.43 \pm 0.15^{*}\end{array}$ \\
\hline$\left[2-{ }^{14} \mathrm{C}\right]$ Pyruvate & $\begin{array}{l}\text { Assimilated } \\
\text { In lipids }\end{array}$ & $\begin{array}{r}1.1 \pm 0.32 \\
0.68 \pm 0.08\end{array}$ & $\begin{array}{l}1.5 \\
0.74\end{array}$ & $\begin{array}{l}0.69 \pm 0.22 \\
0.09 \pm 0.04^{*}\end{array}$ & $\begin{array}{l}0.80 \pm 0.22 \\
0.25 \pm 0.09\end{array}$ \\
\hline$\left[\mathrm{U}-{ }^{14} \mathrm{C}\right]$ Glycerol & $\begin{array}{l}\text { Assimilated } \\
\text { In lipids }\end{array}$ & $\begin{array}{l}0.98 \pm 0.17 \\
0.62 \pm 0.20\end{array}$ & $\begin{array}{l}0.42 \\
0.27\end{array}$ & $\begin{array}{r}0.10 \pm 0.03 \\
0 \pm 0.04\end{array}$ & $\begin{array}{l}0.20 \pm 0.11^{*} \\
0.02 \pm 0.01^{*}\end{array}$ \\
\hline$\left[2-{ }^{14} \mathrm{C}\right]$ Malonate & $\begin{array}{l}\text { Assimilated } \\
\text { In lipids }\end{array}$ & $\begin{array}{l}2.02 \pm 0.58 \\
1.44 \pm 0.34\end{array}$ & $\begin{array}{l}2 \cdot 00 \\
0 \cdot 78\end{array}$ & $\begin{array}{l}0.70 \pm 0.12 \\
0.38 \pm 0.11\end{array}$ & $\begin{array}{l}1 \cdot 73 \pm 0 \cdot 50 \\
0 \cdot 29 \pm 0 \cdot 12\end{array}$ \\
\hline
\end{tabular}

* Doubtfully significantly $(0 \cdot 05<P<0 \cdot 10)$ above zero.

There was some problem in evaluating assimilation and incorporation of carbon into lipids from palmitate in $M$. leprae. In a typical experiment, radioactivity in the lipids of samples (all containing $0.4 \times 10^{10}$ cells of $M$. leprae) from $20 \mathrm{~h}$ incubations with $\left[\mathrm{U}-{ }^{14} \mathrm{C}\right.$ ]palmitate was as follows: live $M$. leprae, 23900 d.p.m.; heat-killed $\left(100^{\circ} \mathrm{C}, 15 \mathrm{~min}\right) M$. leprae 11700 d.p.m.; formaldehyde-killed $M$. leprae, 2300 d.p.m. When $M$. leprae was added to incubations and collected immediately (i.e. at zero time), radioactivity in the lipids was 13500 d.p.m.

Radioactivity in the lipids was similar at zero time and $20 \mathrm{~h}$ for $M$. leprae killed by heating or with formaldehyde, contrasting with live $M$. leprae. Thus the radioactivity in lipids at zero time from live $M$. leprae probably represents radioactivity that is merely adsorbed, and therefore the percentage values (in Table 1) for utilization of exogenous palmitate by $M$. leprae are

$$
\frac{\text { (d.p.m. in } \left.10^{10} M \text {. leprae after } 20 \mathrm{~h}\right)-\left(\text { d.p.m. in } 10^{10} M \text {. leprae at zero time) } \times 10^{2}\right.}{\text { d.p.m. supplied }\left(1.76 \times 10^{6}\right)}
$$

These values will be underestimates if the 'true' control value is that obtained with formaldehyde-killed $M$. leprae.

\section{Incorporation of carbon from exogenous substrates into lipids of $M$. avium and $M$. microti}

Both $M$. microti (Table 2) and $M$. avium (Table 3) that had been grown in Dubos medium incorporated a wide range of carbon sources into lipids in the incubations - using washed, nongrowing organisms - done in this work. Glucose and citrate were both assimilated, but ${ }^{14} \mathrm{C}$ from these two substrates was incorporated very slowly, if at all, into lipids.

$M$. microti and $M$. avium grown in mice incorporated carbon into lipids from some substrates very slowly. In particular, carbon from the $\mathrm{C}-2$ atom of acetate was incorporated into lipids 20 times more slowly in mycobacteria grown in vivo than in the same mycobacteria grown in Dubos medium (Tables 2 and 3). Growth in this medium appeared to reflect the areas of lipid metabolism under investigation more accurately in $\boldsymbol{M}$. microti than in $\boldsymbol{M}$. avium, notably the incorporation of carbon into lipids from glycerol could only be detected in mycobacteria grown in Dubos medium with palmitate in the case of $M$. avium (Table 3). Growth of $M$. microti was inhibited by palmitate: only $20 \mathrm{mg}$ dry wt organisms per flask ( $100 \mathrm{ml}$ medium) was obtained in $14 \mathrm{~d}$ growth as opposed to $35 \mathrm{mg}$ dry wt organisms per flask in Dubos medium with no palmitate. 
Table 3. Incorporation of carbon from substrates into lipids in $M$. avium

\begin{abstract}
Incubations were at $34{ }^{\circ} \mathrm{C}$ and included $3 \times 10^{9}$ to $10^{10}$ organisms, and $20 \mathrm{nmol}{ }^{14} \mathrm{C}$-labelled carbon source (except palmitate : $2 \mathrm{nmol}$ ) in $200 \mu \mathrm{l}$. Each value represents three to five incubations from two or three cultures or isolates except when bacteria were grown on Dubos + glycerol when values represent two incubations from a single, representative culture. Values are expressed as the percentage of radioactivity supplied that was (i) assimilated into intact bacteria or (ii) incorporated into lipids (per $10^{10}$ organisms per hour $\pm \mathrm{SEM}$ ). Incubations were for up to $2.5 \mathrm{~h}$, during which period rates of assimilation and incorporation were linear. In no incubation was $>20 \%$ of the substrate supplied utilized, including substrate converted to ${ }^{14} \mathrm{CO}_{2}$.
\end{abstract}

\author{
${ }^{14}$ C-labelled \\ substrate in \\ incubation medium \\ $\left[\mathrm{U}^{14} \mathrm{C}\right] \mathrm{Palmitate}$ \\ $\left[2-{ }^{14} \mathrm{C}\right]$ Acetate \\ $\left[2-{ }^{14} \mathrm{C}\right]$ Pyruvate \\ $\left[\mathrm{U}-{ }^{14} \mathrm{C}\right]$ Glycerol \\ [2-14 C]Malonate
}

\section{Radioactivity in $M$. avium}

Assimilated In lipids

Assimilated In lipids Assimilated In lipids

Assimilated In lipids Assimilated In lipids

\begin{tabular}{|c|c|c|c|}
\hline \multicolumn{4}{|c|}{ Growth medium } \\
\hline Dubos & $\begin{array}{l}\text { Dubos }+1 \% \\
\text { glycerol }\end{array}$ & $\begin{array}{c}\text { Dubos }+100 \mu \mathrm{g} \\
\text { sodium palmitate } \mathrm{ml}^{-1}\end{array}$ & $\begin{array}{l}\text { C57 Black } \\
\text { mice }\end{array}$ \\
\hline $\begin{array}{l}7.9 \pm 0.33 \\
5.9 \pm 0.63\end{array}$ & $\begin{array}{l}8.8 \\
6.7\end{array}$ & $\begin{array}{l}7.9 \pm 1.6 \\
6.8 \pm 1.8\end{array}$ & $\begin{array}{l}5.9 \pm 0.44 \\
4.3 \pm 0.15\end{array}$ \\
\hline $\begin{array}{r}10.0 \pm 0.18 \\
2.6 \pm 0.64\end{array}$ & $\begin{array}{l}7 \cdot 2 \\
2 \cdot 7\end{array}$ & $\begin{array}{r}1.2 \pm 0.08 \\
0.25 \pm 0.06\end{array}$ & $\begin{array}{l}0.25 \pm 0.01 \\
0.14 \pm 0.01\end{array}$ \\
\hline $\begin{array}{l}0.60 \pm 0.18 \\
0.18 \pm 0.01\end{array}$ & $\begin{array}{l}0.60 \\
0.31\end{array}$ & $\begin{array}{l}0.23 \pm 0.09^{*} \\
0.02 \pm 0.01\end{array}$ & $\begin{array}{l}0.10 \pm 0.05^{*} \\
0.01 \pm 0.001\end{array}$ \\
\hline $\begin{array}{c}8.8 \pm 1.4 \\
0.83 \pm 0.11\end{array}$ & $\begin{array}{l}1 \cdot 02 \\
0 \cdot 33\end{array}$ & $\begin{array}{l}3.25 \pm 0.05 \\
0.26 \pm 0.01\end{array}$ & $\begin{array}{l}0.26 \pm 0.07 \\
0.06 \pm 0.01\end{array}$ \\
\hline $\begin{array}{l}0.42 \\
0.07\end{array}$ & $\begin{array}{l}0.31 \\
0.05\end{array}$ & $\begin{array}{l}0.22 \\
0.03\end{array}$ & $\begin{array}{l}0.02 \\
0.01\end{array}$ \\
\hline
\end{tabular}

* Doubtfully significantly $(0.05<P<0 \cdot 10)$ above zero.

Addition of palmitate to Dubos medium had no effect on growth of $M$. avium. Nevertheless, the fact that palmitate is assimilated and clearly influences metabolism indicates that it is utilized by both these bacteria.

In general, growth rate and viability may affect apparent rates of metabolic activity. However, in these incubations, assimilation of $\left[{ }^{14} \mathrm{C}\right]$ palmitate into both $M$. microti and $M$. avium varied little and could be used as a 'constitutive' activity with which to compare assimilation of, and incorporation of carbon into lipids from other ${ }^{14} \mathrm{C}$-labelled sources.

Tween 80, a detergent containing an oleate moiety in its molecular structure, was routinely used at low concentrations $(0.05$ to $0.1 \%)$ for growth of mycobacteria in vitro. However, its omission from media made no discernable difference to the utilization of ${ }^{14} \mathrm{C}$-labelled carbon sources by $M$. microti and $M$. avium (results not shown). Its omission did make experiments very difficult to do as the mycobacteria used in this study clumped very easily in its absence.

Addition of glycerol to Dubos medium had little effect on the utilization of ${ }^{14} \mathrm{C}$-sources by $M$. microti (Table 2) and $M$. avium (Table 3) grown in its presence. The slightly depressed incorporation of carbon from glycerol into lipids in bacteria grown in the presence of glycerol may be a result of dilution of [U- $\left.{ }^{14} \mathrm{C}\right]$ glycerol in elevated metabolic pools of glycerol and glycerol intermediates in the bacteria. However, growth on glycerol did affect some enzyme activities involved in utilization of carbon sources in lipid metabolism (see section below) so its effect on whole organisms is included in Tables 2 and 3. When M. microti was grown on Youmans and Karlson medium, which contains glycerol, the patterns of both utilization of exogenous carbon sources and enzyme activities (see below) were similar to those in $M$. microti grown in Dubos medium with added glycerol. Since it proved difficult to grow $M$. microti when Youmans and Karlson medium was modified (see Methods), these results are not shown.

\title{
Is palmitate assimilated into $M$. leprae being metabolized?
}

When palmitate is assimilated into organisms it is inevitably extracted into lipid material even if it is not metabolized. However, preliminary evidence for its metabolism in $M$. leprae was obtained. When neutral lipids from $20 \mathrm{~h}$ incubations of live $M$. leprae with $\left[\mathrm{U}-{ }^{14} \mathrm{C}\right]$ palmitate 
were fractionated ( $\sim 80000$ d.p.m. applied to HPTLC plate), $91 \%$ of the radioactivity appeared in the free fatty acid fraction and $3 \%$ in the monoacylglycerol fraction. In contrast, in the control incubations, neutral lipids from incubations either with no bacteria but with an extract of armadillo liver ( $1 \mathrm{mg}$ protein), or with $\left[\mathrm{U}-{ }^{14} \mathrm{C}\right]$ palmitate alone, 94 to $95 \%$ of the radioactivity appeared in the free fatty acid fraction and $0.2 \%$ in the monoacylglycerol fraction. Otherwise, the radioactivity in individual fractions was similar within $\pm 0.2 \%$ to that in incubations with live $M$. leprae and control incubations. Results presented earlier in the paper suggest that $\sim 60 \%$ of the radioactivity applied to the HPTLC plate may represent adsorbed [U- $\left.{ }^{14} \mathrm{C}\right]$ palmitate; thus probably nearer to 7 to $8 \%$ of the $\left[\mathrm{U}^{14} \mathrm{C}\right]$ palmitate truly assimilated by $M$. leprae is being incorporated into monoacylglycerols.

Remarkably rapid evolution of ${ }^{14} \mathrm{CO}_{2}$ was observed in incubations of $M$. leprae with [U- ${ }^{14} \mathrm{C}$ ]palmitate : $16 \cdot 3 \pm 4 \cdot 9 \%$ (SEM) of palmitate supplied was converted to ${ }^{14} \mathrm{CO}_{2}$ in $20 \mathrm{~h}$ by $10^{10}$ organisms (see Table 1 for details of incubations and the assimilation and incorporation into lipids). With all other ${ }^{14} \mathrm{C}$-labelled sources, the radioactivity evolved as ${ }^{14} \mathrm{CO}_{2}$ was between $10 \%$ and $60 \%$ of the radioactivity assimilated for either $M$. avium, $M$. microti (both grown either in vivo or in vitro) or $M$. leprae.

\section{Anabolic fate of glycerol}

Apart from palmitate, comparative studies using $M$. microti, $M$. avium and $M$. leprae could only be done on the metabolism of glycerol, since insufficient carbon was assimilated into lipids when $M$. leprae was incubated with other carbon sources. An interesting difference in the anabolic fate of glycerol in $M$. avium and $M$. microti on the one hand, and $M$. leprae on the other, was observed. After incubations ( $1 \mathrm{~h}$ for $M$. microti, $2 \mathrm{~h}$ for $M$. avium) with [U- $\left.{ }^{14} \mathrm{C}\right] \mathrm{glycerol}$, radioactivity ( 30 to $42 \%$ of the neutral lipids separated by HPTLC) was observed in the fatty acid fractions, regardless of the conditions under which the organisms had been grown. Further radioactivity was observed in acylglycerol fractions (results not shown). However, when neutral lipids from $20 \mathrm{~h}$ incubations of live $M$. leprae with $0.5 \mu \mathrm{Ci}\left[\mathrm{U}-{ }^{14} \mathrm{C}\right]$ glycerol were fractionated ( $\sim 7000$ d.p.m. applied to HPTLC plate), $92 \%$ of the radioactivity appeared in acylglycerol fractions but none at all in the free fatty acid fraction. Thus it appeared that the $\left[\mathrm{U}-{ }^{14} \mathrm{C}\right]$ glycerol assimilated by $M$. leprae was only being esterified with endogenous fatty acyl moieties while in $M$. avium and $M$. microti some carbon from $\left[\mathrm{U}^{14} \mathrm{C}\right] \mathrm{glycerol}$ was being used (presumably metabolized via acetyl-CoA) for fatty acid biosynthesis or elongation.

In order to confirm that the carbon from glycerol was not being assimilated into fatty acyl moieties of acylglycerols in $M$. leprae, neutral lipids (two samples containing $\sim 7000$ d.p.m. extracted from a replicate incubation of $M$. leprae with $0.5 \mu \mathrm{Ci}\left[\mathrm{U}-{ }^{14} \mathrm{C}\right] \mathrm{glycerol}$ were each digested for $30 \mathrm{~min}$ at $37^{\circ} \mathrm{C}$ with lipase (Candida cylindrica; from Sigma; $0.2 \mathrm{mg}$ dry wt dissolved in $50 \mu 130 \mathrm{~mm}$-Tris/ $\mathrm{HCl}, \mathrm{pH} \mathrm{7.6}$, and mixed with the lipid sample). One digested sample was dried and then dissolved in $25 \mu \mathrm{l} \mathrm{CHCl}_{3}$ and applied to an HPTLC plate. When neutral lipids were fractionated only $15 \%$ of the radioactivity appeared in acylglycerol fractions and again, none at all in the free fatty acid fraction. The second digested sample was acidified with $1 \mathrm{ml} 0 \cdot 1$ $\mathrm{M}-\mathrm{HCl}$ and extracted three times with $3 \mathrm{ml}$ light petroleum (b.p. $30-40^{\circ} \mathrm{C}$ ). The combined light petroleum extracts were backwashed twice with $2 \mathrm{ml}$ distilled water; $97 \%$ of the radioactivity remained in the aqueous phase. Together these observations show that the carbon incorporated from glycerol into acylglycerols in $M$. leprae was all incorporated into the glycerol moiety.

\section{Enzymes involved in utilization of carbon sources in lipid metabolism}

The enzymes for conversion of acetate to acetyl-CoA, pyruvate to acetyl-CoA, of the glyoxylate bypass and the competing isocitrate dehydrogenase were assayed in $M$. leprae, and $M$. avium and $M$. microti grown in mice and the growth media described in Methods and above. Activities of all these enzymes in mycobacteria grown in vivo are presented in Table 4. Observations on their variation in the same Mycobacterium grown in different media are presented below. Some assays for each enzyme were done using dialysed extracts in case inhibitors were present in undialysed extracts. However, no marked difference of any activity was found between dialysed and undialysed extracts. 
Table 4. Enzymes involved in C-2 metabolism in mycobacteria from host tissues

Enzyme assays were done at $25^{\circ} \mathrm{C}$ as indicated in Methods. Values, \pm SEM, represent specific activities determined by assaying in triplicate extracts prepared from bacteria from two or three isolates (except pyruvate dehydrogenase - one isolate only used, and phosphotransacetylase in $M$. leprae, five isolates used).

Specific activity $\left[\mathrm{mU}\left(\mathrm{mg}\right.\right.$ protein $\left.\left.{ }^{-1}\right)\right]$

in cell-free extracts of :

Enzyme

Acetate kinase

Phosphotransacetylase

Pyruvate dehydrogenase

Isocitrate dehydrogenase $\dagger$

Isocitrate lyase

Malate synthase
M. microti OV 254

$$
\begin{gathered}
0.35 \pm 0.04 \\
27 \pm 7.4 \\
0.39 \\
13 \pm 2.3 \\
1.1 \pm 0.13 \\
11.4 \pm 0.5
\end{gathered}
$$

M. avium CR 1/69

$0.96 \pm 0.11$

$6 \cdot 8 \pm 1 \cdot 2$

$0 \cdot 29$

$7 \cdot 8 \pm 0 \cdot 3$

$1 \cdot 6 \pm 0.44$

$8 \cdot 5 \pm 3 \cdot 4$

* Mean of activity in the five extracts; no activity detected in two of them; not significantly $(P>0 \cdot 10)$ above zero.

$\dagger$ Activity five to eight times lower in extracts made from bacteria treated with $\mathrm{NaOH}$. All other enzymes were present at similar activities in $\mathrm{NaOH}$-treated and untreated bacteria.

Acetate kinase and phosphotransacetylase. Acetate kinase was present in all extracts of $M$. leprae in which it was assayed for. However, phosphotransacetylase was only possibly detected, at very low activity, in three extracts out of five. This finding might be due to the activity (see Table 4) being little above the minimum detectable $\left[\sim 0.01 \mathrm{mU}\right.$ (mg protein) ${ }^{-1}$ in the assay using acetyl-CoA and phosphate as substrates] but as activity is not significantly $(P>0 \cdot 10)$ above zero the existence of phosphotransacetylase in $M$. leprae remains in doubt. Mycobacteria convert acetate to acetyl-CoA using these two enzymes (Ratledge, 1982) but it might be that $M$. leprae has an acetyl-CoA synthetase instead. The synthetase catalyses the direct conversion of acetate to acetyl-CoA, at the same time converting ATP to ADP. Therefore, the assay for acetate kinase, dependent upon detecting ADP formation, could indicate acetylCoA synthetase activity also. However, this acetate-dependent conversion of ATP to ADP was not stimulated by $\mathrm{CoA}$ at $0.1,0.25$ or $0.5 \mathrm{mM}$. Furthermore, $0.1 \mathrm{mM}$-DTNB, which would bind any $\mathrm{CoA}$ in extracts of $M$. leprae, failed to inhibit completely acetate-dependent conversion of ATP to ADP, indicating that CoA was not necessary and the $M$. leprae possesses a true acetate kinase.

In a further attempt to detect acetyl-CoA synthetase, extracts of $M$. leprae were assayed for the enzyme using the radiochemical assay described in Methods. Acetyl-CoA was formed at the rate of 61-84 pmol min ${ }^{-1}$ (mg protein) ${ }^{-1}$ (range; three extracts, one of which was made from $\mathrm{NaOH}-$ treated $M$. leprae). However, this could be a result of conversion of acetate first to acetyl phosphate, then to acetyl-CoA; since radioactivity appeared in acetyl phosphate during this assay equivalent to $980-1860 \mathrm{pmol} \mathrm{min}^{-1}$ (mg protein) ${ }^{-1}$ and phosphotransacetylase, the enzyme for the second step was detected spectrophotometrically in two of the three extracts incubated with $\left[{ }^{14} \mathrm{C}\right]$ acetate in these experiments, at just above the limit for its detection $[\sim 0 \cdot 05$ $\mathrm{mU}$ (mg protein) $)^{-1}$ - i.e. $50 \mathrm{pmol}$ acetyl-CoA formed $\mathrm{min}^{-1}$ (mg protein) ${ }^{-1}$ from acetyl phosphate].

Acetate kinase and phosphotransacetylase activities varied considerably in extracts prepared from both $M$. microti and $M$. avium grown in the different media used in this study. Acetate kinase activity in extracts of mycobacteria grown in vivo (Table 4) was relatively low. However, phosphotransacetylase activity was relatively high in extracts of $M$. microti but relatively low in extracts of $M$. avium (though still easily detected), both grown in vivo (Table 4). When $M$. microti was grown in Dubos medium or Dubos with added palmitate both activities were relatively high: acetate kinase was detected at 4.6-6.2 $\mathrm{mU}$ (mg protein $)^{-1}$ and phosphotransacetylase was detected at 19-34 mU (mg protein $)^{-1}$. Only when they were grown in Dubos with glycerol added, or in Youmans and Karlson medium (which contains glycerol) were activities comparable with 
activities found in mycobacteria grown in vivo: when they were in Dubos with glycerol added, acetate kinase and phosphotransacetylase were detected at 0.20 and $2.7 \mathrm{mU}$ (mg protein $)^{-1}$ respectively in $M$. microti and 0.69 and 2.7 to $3.5 \mathrm{mU}(\mathrm{mg} \text { protein })^{-1}$ respectively in $M$. avium. The levels of acetate kinase and phosphotransacetylase activity do not correlate with the ability of intact bacteria to incorporate carbon from acetate into lipids (see Tables 2 and 3) but some activity is essential for conversion of acetate to acetyl-CoA in mycobacteria.

Isocitrate lyase and malate synthase. Both these enzymes were detected in extracts from $M$. leprae (Table 4). Their activities in both $M$. microti and $M$. avium grown in vivo are also shown in Table 4. Compared with activity in mycobacteria grown in vivo isocitrate lyase activity in bacteria grown on Dubos with glycerol added was about half, and in bacteria grown on Dubos, or Dubos with added palmitate, about double. A similar pattern of variation between activities in extracts from mycobacteria grown in the different media above and in mice was observed for malate synthase, but activity varied fivefold in $M$. microti, and sevenfold in $M$. avium.

Isocitrate dehydrogenase and pyruvate dehydrogenase. The presence of both these enzymes in $M$. leprae was confirmed (Table 4). Pyruvate dehydrogenase appeared constitutive, activity varying from 0.25 to $0.29 \mathrm{mU}$ (mg protein $)^{-1}$ in extracts from $M$. avium and 0.33 to $0.48 \mathrm{mU}$ (mg protein $)^{-1}$ in extracts from $M$. microti whether the organisms were grown in Dubos, Dubos with glycerol or palmitate added, or in mice (Table 4).

Isocitrate dehydrogenase activity did vary depending on how bacteria were grown, but not to any discernible pattern. For instance, in $M$. microti, activity was higher when bacteria were grown in Dubos with glycerol added $\left.[35 \mathrm{mU} \text { (mg protein })^{-1}\right]$ than when they were grown in Dubos with palmitate added [5.4 mU (mg protein) ${ }^{-1}$ ]. In contrast, in $M$. avium, activity was higher when bacteria were grown in Dubos with palmitate added [8.8 to $22.5 \mathrm{mU}$ (mg protein $)^{-1}$; three extracts] than when they were grown in Dubos with glycerol added [5.7 $\mathrm{mU}$ (mg protein $)^{-1}$. Isocitrate dehydrogenase activity was labile when host-grown mycobacteria were treated with $0.5 \mathrm{M}-\mathrm{NaOH}$ (Table 4). The objective of the treatment was to abolish hostderived activities adsorbed to the surface of mycobacteria (Kanai, 1967; Wheeler, 1984b) but the activity in extracts of untreated host-grown mycobacteria is considered authentic since previous studies using PAGE showed that no tissue-derived isocitrate dehydrogenase could be found in such extracts (Wheeler, 1984a).

\section{DISCUSSION}

M. leprae, like all mycobacteria, invests a great deal of effort in synthesizing lipids (about $40 \%$ of its dry weight). Many lipids are complex and characteristic such as mycolic acids in the cell wall, glycolipids and some membrane lipids. All of these it must synthesize itself. However, it is far from certain that $M$. leprae can synthesize all the intermediates required for complex lipid synthesis. The results obtained here may indicate that $M$. leprae lacks the ability to synthesize some intermediates in lipid synthesis, in particular fatty acids, from simple carbon compounds. In that case, the intracellular $M$. leprae would depend to some extent on being able to scavenge fatty acids from its host.

Alternatively, the pathways for the synthesis of intermediates in lipid synthesis may be repressed or inhibited in mycobacteria when they are growing in the host, or more generally with an exogenous source of lipid. Fatty acid synthesis de novo in mycobacteria is known to be exquisitely sensitive to feedback inhibition by fatty acyl-CoA (Bloch, 1977), and repression or inhibition of fatty acid synthesis appears to occur in $M$. convolutum grown in the presence of alkenes (Ascenzi \& Vestal, 1979) and M. lepraemurium grown in lipid-rich medium (Kusaka, 1977). Results obtained in this work also suggest that repression or inhibition does occur. Both intact $M$. microti and $M$. avium organisms incorporated carbon from acetate, pyruvate or glycerol considerably more slowly (in many cases over 20 times more slowly) when they were grown in vivo, or in vitro in the presence of palmitate (a fatty acid) than in Dubos medium alone (i.e. in the absence of added fatty acids) and it may be that the failure of $M$. leprae isolated from tissue to incorporate carbon from most carbon sources into lipid is also a result of metabolic control of activities.

Two substrates - acetate (at $\mathrm{pH} 7$ ) and malonate - were not assimilated into $M$. leprae 
organisms and therefore could not be utilized in lipid synthesis. Transport of substrates might itself be subject to metabolic control, certainly assimilation of acetate and glycerol into $M$. avium or $M$. microti grown in vivo takes place relatively slowly and this might limit the rate of lipid synthesis. However, some substrates (e.g. citrate) are clearly assimilated into mycobacteria but not used in lipid synthesis.

Lack of enzyme activity may explain the failure to use some carbon sources in lipid synthesis. Although isocitrate lyase, malate synthase and acetate kinase were fairly readily detected in $M$. leprae, phosphotransacetylase activity could not reliably be detected in $M$. leprae. Although phosphotransacetylase activity was susceptible to metabolic control in $M$. microti and $M$. avium its activity remained high when bacteria were grown in vitro in the presence of added palmitate and in vivo in the case of $M$. microti, so experiments with $M$. microti and $M$. avium cannot explain why phosphotransacetylase activity is absent or extremely low in $M$. leprae. Deficiency of phosphotransacetylase in $M$. leprae may explain its failure to utilize exogenous acetate, since the enzyme for conversion of acetate to acetyl phosphate (acetate kinase) was detected but no route for the rapid formation of acetyl-CoA from either acetate or acetyl phosphate was shown. Acetyl-CoA is essential for lipid synthesis, and it would appear that pyruvate dehydrogenase, which converts pyruvate to acetyl-CoA, is the key enzyme for acetyl-CoA production from carbohydrates in $M$. leprae. It seems that $M$. leprae is unable to metabolize efficiently any acetate which might be formed as a result of deacetylation reactions. Such an inability is not fatal, but restricts the number of carbon sources on which the microbe can grow, as evinced by mutant $E$. coli strains which cannot convert acetate to acetyl-CoA (Le Vine et al., 1980).

Apart from the deficiency of phosphotransacetylase in $M$. leprae, most of the present findings on $M$. leprae might be explained as the metabolic activities of a Mycobacterium growing as in vivo. The other unusual finding in $M$. leprae was the failure to detect fatty acid synthesis or elongation (no radioactivity in fatty acids after incubations with $\left[{ }^{14} \mathrm{C}\right] g l y c e r o l$ ). This is probably not a result of repression or inhibition of activity by lipids since some radioactivity was always traced in fatty acids after similar incubations with $\boldsymbol{M}$. avium or $\boldsymbol{M}$. microti grown in vivo or in vitro in the presence of palmitate, when fatty acid synthesis would be repressed. An explanation of this finding, and further elucidation of lipid biosynthesis in $M$. leprae would appear to await the next logical step - a study of the enzymes for fatty acid synthesis de novo, and for elongating existing fatty acids (such as palmitate which is so readily utilised) in intracellular mycobacteria including $M$. leprae.

Finally, formation of ${ }^{14} \mathrm{CO}_{2}$ from $\left[{ }^{14} \mathrm{C}\right]$ palmitate is the most easily detectable activity of $M$. leprae so far found, and this activity is inhibited by a number of antileprosy agents (Franzblau, 1988). Thus, it appears very promising for use in a simple, sensitive method to screen for activity of antileprosy agents.

We thank Kathleen Bulmer for excellent technical assistance. P.R.W. is grateful to the MRC, LEPRA, and the UNDP/World Bank/WHO Special Programme for Research and Training in Tropical Diseases for financial support during the course of this investigation. LEPRA and the WHO (IMMLEP programme) provided funds for the maintenance of armadillo colonies.

\section{REFERENCES}

Andrejew, A., Orfanelit, M.-T. \& Desbordes, J. (1975). Purification et propriétés des acétokinases du BCG et de Mycobacterium phlei. Biochemie 57, 1389 1390.

Andrejew, A., Orfanelli, M.-T. \& Desbordes, J. (1976). Phosphotransacétylases du BCG et de $\mathrm{Myco}$ bacterium phlei. Biochemie 58, 879-880.

AsCenzi, J. M. \& Vestal, V. R. (1979). Regulation of fatty acid biosynthesis by carbon substrates in Mycobacterium convolutum. Journal of Bacteriology 137, 384-390.

BLoch, K. (1977). Control mechanisms for fatty acid synthesis in Mycobacterium smegmatis. Advances in Enzymology 45, 1-84.

BrenNaN, P. J. (1983). The phthiocerol-containing surface lipid of Mycobacterium leprae - a perspective of past and present work. International Journal of Leprosy 51, 387-396.

ChaDwick, M. V. (1982). Mycobacteria. Institute for Medical Laboratory Sciences Monographs. Bristol: P. S. G. Wright.

Cho, S. N., Hunter, S. W., Gelber, R. H., Rea, T. H. \& BRENNAN, P. J. (1986). Quantitation of the phenolic glycolipid and relevance to glycolipid antigenemia in leprosy. Journal of Infectious Diseases 153, 560-569.

Dhariwal, K. R., Chander, A. \& VenkitasubraManian, T. A. (1978). Turnover of lipids in Mycobacterium smegmatis CDC 46 and Mycobacterium phle ATCC 354. Archives of Microbiology 116, 69-75. 
Dixon, G. H. \& Kornberg, H. L. (1959). Assay methods for key enzymes of the glyoxylate cycle. Biochemical Journal 72, 3P.

DRAPER, P. (1984). Wall biosynthesis: a possible site of action for new antimicrobial drugs. International Journal of Leprosy 52, 527-532.

FranzblaU, S. G. (1988). Oxidation of palmitic acid by Mycobacterium leprae in an axenic medium. Journal of Clinical Microbiology 26, 18-21.

KANAI, K. (1967). Detection of host originated acid phosphatase on the surface of in vivo grown tubercle bacilli. Japanese Journal of Medical Science and Biology 104, 37-45.

KuSAKA, T. (1977). Fatty acid synthesizing enzyme activity of cultured Mycobacterium lepraemurium. International Journal of Leprosy 45, 132-144.

LE VINE, S. M., ARDEshir, F. \& AMES, G. F.-L. (1980). Isolation and characterization of acetate kinase and phosphotransacetylase mutants of Escherichia coli and Salmonella typhimurium. Journal of Bacteriology 143, 1081-1085.

RATLEDGE, C. (1982). Lipids: cell composition, fatty acid biosynthesis. In The Biology of the Mycobacteria, vol. 1, pp. 53-93. Edited by C. Ratledge \& J. Stanford. London: Academic Press.

Reddy, T. L. P. \& Venkitasubramanian, T. A. (1975). Metabolism of mycobacteria. Journal of Scientific and Industrial Research 34, 319-328.

WheELER, P. R. (1983). Catabolic pathways for glucose, glycerol and 6-phosphogluconate in $\mathrm{Myco}$ - bacterium leprae grown in armadillo tissues. Journal of General Microbiology 129, 1481-1495.

WHEELER, P. R. (1984a). Oxidation of carbon sources through the tricarboxylic acid cycle in Mycobacterium leprae grown in armadillo liver. Journal of General Microbiology 130, 381-389.

WheELER, P. R. (1984b). Metabolism in Mycobacterium leprae : its relation to other research on $M$. leprae and to aspects of metabolism in other mycobacteria and intracellular parasites. International Journal of Leprosy 52, 208-230.

WHEELER, P. R. (1987). Biosynthesis and scavenging of purines by pathogenic mycobacteria including Mycobacterium leprae. Journal of General Microbiology 133, 2999-3011.

Wheeler, P. R. \& Gregory, D. (1980). Superoxide dismutase, peroxidatic activity and catalase in Mycobacterium leprae purified from armadillo liver. Journal of General Microbiology 121, 457-464.

Wheeler, P. R., Bharadwaj, V. P. \& Gregory, D. (1982). $\quad N$-Acetyl- $\beta$-glucosaminidase, $\beta$-glucuronidase and acid phosphatase in Mycobacterium leprae. Journal of General Microbiology 128, 1063-1071.

World Health ORganization (1980). UNDP/World Bank/WHO Special Programme for Research and Training in Tropical Diseases. Report of the Fifth Meeting on the Immunology of Leprosy (IMMLEP). TDR/IMMLEP-SWG (5)/80.3, Annex 4, p. 23. Geneva: World Health Organization. 